\title{
Local Economic Impact of Wind Energy Development: Analysis of the Regulatory Framework, Taxation, and Income for Galician Municipalities
}

\author{
Damián Copena $^{1, * \mathbb{D}}$, David Pérez-Neira ${ }^{2} \mathbb{D}$ and Xavier Simón ${ }^{1}$ \\ 1 Department of Applied Economy, FCEE, Vigo University, 36310 Vigo, Spain; xsimon@uvigo.gal \\ 2 Department of Economy and Statistics, Leon University, 24071 León, Spain; dpern@unileon.es \\ * Correspondence: decopena@uvigo.gal; Tel.: +34-986-812506
}

Received: 13 March 2019; Accepted: 17 April 2019; Published: 23 April 2019

check for updates

\begin{abstract}
Wind energy has rapidly developed in the last decades, generating economic impacts at different territorial scales and contributing to rural development. However, few research works have analysed its economic impact at a local scale, especially in rural areas. Galicia is a Spanish region in which $3300 \mathrm{MW}$ of wind energy have been installed in rural municipalities with low levels of socioeconomic activity and important socio-environmental problems. In this sense, the objective of this work is to analyse the local revenues directly derived from wind power activity in relation to changes in the regulatory framework (1995-2017), as well as to quantify those revenues for the year 2017. For this purpose, information has been systematically collected from secondary sources and complemented with 10 years of field and monitoring work on site at the wind farms. This article reveals the relationship between the regulatory framework and the main sources of income associated with wind power generation (conventional and specific taxes, municipal ownership, and other revenues). In 2017, these revenues amounted to 17.8 million euros. This work discusses how the public policies implemented during the analysed time period limited the direct economic impacts of the installation of wind farms on Galician rural municipalities, and consequently hindered rural development.
\end{abstract}

Keywords: municipalities; public policies; rural development; wind farms; renewable energy

\section{Introduction}

The development of the different forms of renewable energy has, in the last decades, become a priority at both a global level [1] and at the European scale [2]. Among those forms, wind power is one of the most prominent renewable technologies, as has been widely stated in the literature [3]. Thus, this type of energy has rapidly expanded across the world [4,5], facilitating the supply of energy from local and renewable resources and contributing to the fight against climate change [6]. Besides, the installation of wind farms has generated socioeconomic impacts at different territorial levels (national, regional, local), fostering rural development to a greater or lesser extent $[7,8]$. For instance, Varela and Sánchez [9] have analysed the importance of wind energy impacts on employment generation and the gross domestic product of peripheral regions. Slattery et al. [10] have shown how the installation of wind farms has had socioeconomic effects at a regional and, most especially, at a local level in rural areas of Texas (United States). In addition, recent works have underlined how renewable energy can be an opportunity to create more dynamic local communities [11], to achieve sustainable development at the local government level [12], and to encourage rural development through the sustainable exploitation of local resources [13] (see Section 2).

Galicia is a region situated in the northwest of Spain. The number of wind farms in the region has increased exponentially in the last few decades. In 20 years, around 4000 wind turbines have 
been installed in more than 150 wind farms across Galician rural areas. These wind farms have over 3300 MW distributed to 107 out of 315 municipalities in Galicia (Figure 1). In 2016, Galicia was, after Germany and Denmark, the third largest territory of the European Union in terms of wind power per unit area. On the other hand, it is important to point out that almost all of the wind turbines are located in rural municipalities with serious structural socioeconomic problems. To the low population density (98\% of wind turbines are found in municipalities with less than 150 inhabitants per $\mathrm{km}^{2}$ ), it is possible to add the high ageing index (Galicia is the second autonomous region in Spain with the highest index) [14], the loss of agricultural employment (which has reduced by 65\% in the last 15 years) and the increase in the number of abandoned towns and villages (from 1064 to 1726 in the 2000-2017 period) [15]. All of these factors have led to the progressive abandonment of cropland and forest areas [16], causing important environmental problems such as forest fires [17].

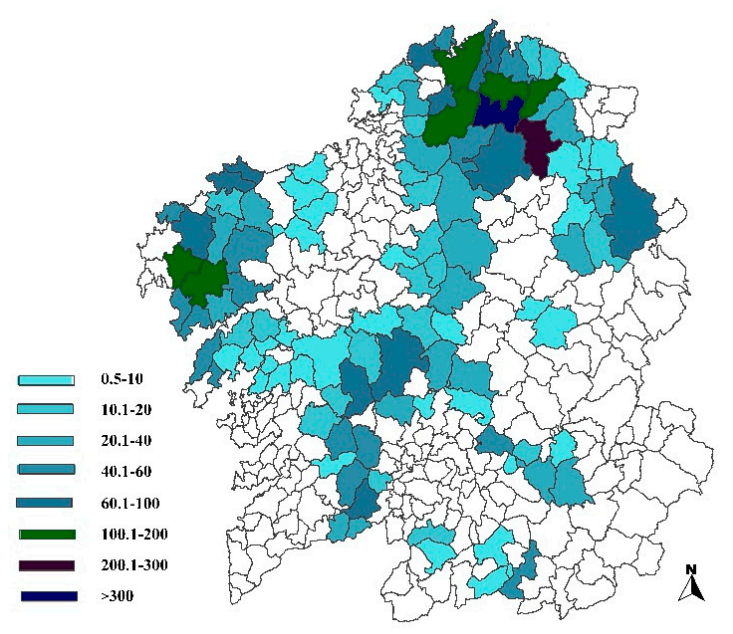

(a)

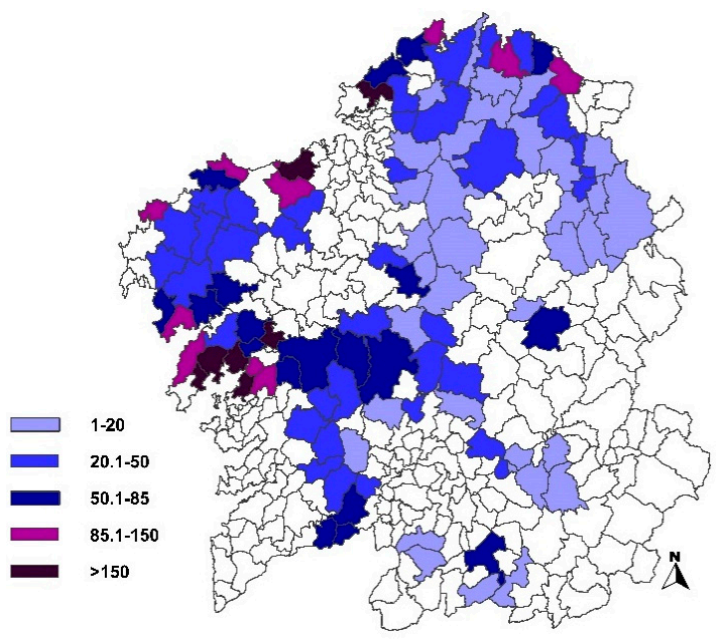

(b)

Figure 1. Territorial distribution of: (a) number of wind turbines (2018), and (b) population density (inhabitants per $\mathrm{km}^{2}$ ) in municipalities with wind farms in Galicia (2016). As can be seen, most municipalities with wind farms in their territories have low population densities, often below 50 inhabitants per square kilometre, which makes this new economic activity even more relevant for rural areas. Municipalities with more than 100 wind turbines have an average population density of 20.6 inhabitants per square kilometre, while the density of those with less than 10 wind turbines is 113.5 inhabitants per square kilometre. Source: Own elaboration from: (a) Socioeconomic Information Database of Wind Energy in Galicia (SIDWEG) [18]; (b) Instituto Galego de Estatística (IGE) [19].

In this context, wind energy emerges as a great opportunity to reverse negative trends and revitalise rural municipalities in the region. In this sense, the new local revenues associated with wind power development and the corresponding public policies are two key aspects of the analysis of potential opportunities for the development of rural territories [20]. The objective of this work is three-fold: (a) to identify, characterise, and analyse the dynamics of the main direct revenues derived from wind power activity and earned by rural municipalities between 1995-2017; (b) to make a quantitative estimation of the local revenues in the last year for which information was available (2017); and (c) to discuss the influence of the Galician and Spanish regulatory framework on the results. This article reflects on the economic importance of the main sources of income identified: the revenues obtained from singular wind farms, conventional taxes, the canon eólico (wind power tax), and the Environmental Compensation Fund, and other possible revenues such as those derived from collaboration agreements and the renting of public property (see Section 4). In order to conduct this research, a systematic collection of information from secondary sources has been carried out and completed with field and monitoring work at the wind farms over 10 years (2008-2017). As a result of this research process, a database of socioeconomic information on wind energy in Galicia 
was created (Socioeconomic Information Database of Wind Energy in Galicia, SIDWEG) (see [18]); this database has been the main source of information for the present work (see Section 3). Thus, this article contributes new and relevant socioeconomic information to the political debate on the relevance of wind energy and its regulatory framework for rural development processes in relation to the endogenous potentialities of the different territories.

\section{Local Economic Impacts, Regulatory Framework and Rural Development Associated with Wind Energy}

The local socioeconomic impacts of wind farms in rural areas have been poorly studied $[10,21]$. In spite of this, it is possible to identify four different research lines among the works published. First of all, there are studies focused on the direct economic impacts on the local territory. Taxes are one of the local sources of revenue that are most often analysed in this literature [22,23]. Thus, in some countries, local administrations receive, via taxes, direct contributions from the turnover of wind farms located in their territories. For instance, this is the case of Greek municipalities, which receive annual payments representing 3\% of the turnover of wind farms built within their territories [24]; in Portugal, the annual amount corresponds to $2.5 \%$ of the turnover [25]. For the United States, Slattery et al. [10] have estimated that the payment of taxes associated with wind power activity to local governments can range between 4000-12,000 US dollars per MW. On the other hand, the establishment of locally owned wind farms also has direct economic impacts on the area, as seen in England [26], the United States [27], Germany, or Denmark, where in 2010, 15\% of the wind turbines were owned by cooperatives controlled by the local population [28].

Second, there are research works that discuss the possibilities of local development and revitalisation associated with wind power activity. In the literature, there is a strong consensus on the potential of renewable energy as a driver for the sustainable development of territories [11,12,29,30], which is a fact that is also recognised by the European regulations [2]. Thus, Munday et al. [31] have analysed the benefits that wind energy has for local communities in Scotland, while Copena and Simón [20] have shown how payments received by landowners may foster initiatives to revive local areas in Galicia. Delicado et al. [21] have studied how, in the case of Portugal, the benefits and positive impacts of wind farms are perceived as indirect and quite modest. From another perspective, Castleberry and Greene [32] have examined the specific case of public schools in Oklahoma, finding significant differences in revenues among school districts with and without wind farms in their territories. Okkonen and Lehtonen [33] have highlighted the importance of wind revenues in the provision and maintenance of basic services for the population of northern Scotland.

Third, there are research works focused on studying the role of economic impacts on the local acceptance of wind farms. Economic benefits in particular are presented as strongly linked to the local acceptance of wind farm projects [22]. Thus, Liebe et al. [34], studying the case of Germany, revealed a positive relationship between the local ownership of wind farms and the local acceptance of renewable energy plants, while Slattery et al. [35] pointed to the increase in local revenues via taxes as one of the elements explaining the greater support for this type of project in the United States. Other authors such as Jami and Walsh [36] have also described local ownership and the increase in revenues via taxes as key for the acceptance of wind farms in Ontario (Canada), while Mundaca et al. [37] connected local ownership with distributive justice and the consent for wind farms in Denmark. In the same line, the increment of local revenues through taxes was a strong incentive for Portuguese local authorities to approve the construction of wind farms [21], which is a dynamic that has also been specifically pointed out in relation to rural contexts with low economic activity [38].

Finally, the fourth research line includes works that analyse the importance of the institutional and regulatory frameworks of the wind industry and their influence on the three previous aspects. Certainly, the scope of the local economic impacts of wind energy is limited by the public policies regulating wind power activity [39]. For instance, in Denmark, $20 \%$ of the ownership of a wind farm is offered to the public in the form of shares at a cost price, which is a norm that fosters the 
increase of local revenues [40,41]. In France, a specific wind tax has been created for the purpose of granting municipalities the possibility of participating in the income generated by wind farms [42]. In the United States, local administrations have had a crucial role in the planning and development of regulations; they are even entitled to decide the location of wind farms [43]. Something similar occurs in Sweden, where municipalities hold veto power over the projects [44], or in the United Kingdom, where governance processes at a local level are common [45]. On the contrary, in contexts where local ownership of wind farms is rare and the local authorities have a limited negotiation capacity, the structural interests of wind power companies (whether national or international) weaken the possible benefits and positive impacts of this activity [21].

\section{Materials and Methods}

\subsection{Gathering and Selection of Information}

In order to carry out this research, a systematic gathering of information from secondary sources has been performed and completed with field and monitoring work at wind farms over a 10-year period (2008-2017). Among the secondary sources, which are mostly public databases, regulatory documents and official journals were systematised for the 1995-2017 period (see Table 1). Complementarily, the field work consisted of the collection of socioeconomic information on the Galician municipalities affected by wind power projects. For this purpose, participatory research techniques were used [46,47], and a total of 106 semi-structured interviews were conducted on the wind farms in operation. The main source of information for this research paper came from the systematisation of data gathered from secondary sources; the field work was a complementary source that was used mainly to have access to the renting contracts signed by the tenants of municipally-owned land and to compile the few collaboration agreements drawn up by companies and municipalities. The interviews were directly conducted with key actors in the municipalities with wind farms in their territories $(71 \%$ of them were local inhabitants, $19 \%$ were political representatives at the local government, and $10 \%$ were promoters and managers of companies providing auxiliary and other services to the wind farms). The semi-structured interviews aimed at gathering information on wind power projects that could not be obtained from the above-mentioned secondary sources. This information included: the type of local participation in the approval procedure for the installation of wind farms; local revenues from wind farms and instruments used for the transfer of those revenues; role of the municipalities in the development of wind farms; and the ultimate destination of wind revenues.

As a result of this process, a Socioeconomic Information Database of Wind Energy in Galicia was created [18], containing wind-related administrative, economic, social, and institutional data of the 1995-2017 period for all the operating wind farms and the municipalities affected by them in the Galician territory. The SIDWEG is an innovative database that includes both quantitative and qualitative information at four different scales: wind farm, municipality, province, and the whole region of Galicia. The SIDWEG contains systematised public information on technological aspects (unit capacity, total capacity, number of wind turbines, technology used, etc.), economic aspects (investments made, annual production, premiums received, local public revenue, etc.), and territorial aspects (areas affected, land occupied, number of wind turbines per municipality, etc.). Finally, the SIDWEG comprises social information (actors identified, the role played by each of them, etc.) and economic information for the above-mentioned four scales regarding the income obtained by the owners of wind farms and the main destination of that income. For this work, we have specifically used the sub-databases included in Table 1 with disaggregated local information. The four sub-databases were the ones containing: (1) socio-administrative data, (2) economic data, (3) public income data, and (4) landowner income data. The first one allows characterising wind farms in operation and those awaiting administrative processing, facilitating a constant monitoring of the administrative situation of every wind farm. The second database synthesises information about the production and economic turnover of wind farms, including those owned by the local administrations. The third database 
systematises the flows of wind revenues earned by the municipalities, which were classified as follows: (i) revenues derived from wind taxation (the canon eólico and the Environmental Compensation Fund, hereinafter ECF); (ii) inflowing revenues from conventional taxes; and (iii) revenues obtained from the local ownership of wind farms (municipal singular wind farms). This database includes as well, to the extent that it is possible, information on the final destination of the local revenues associated with wind power activity. Finally, it reflects other possible wind-related incomes, more specifically, those linked to the leasing contracts and collaboration agreements drawn up between companies and municipalities.

Table 1. Summary of the main sources of information and fields of the SIDWEG used for the analysis of the local economic impacts of wind energy in Galicia.

\begin{tabular}{|c|c|c|c|}
\hline Database & Sources of Information & Content & Relevance for This Article \\
\hline 1. Socio-administrative & $\begin{array}{l}\text { - Official Journal of Galicia } \\
\text { - Official State Gazette } \\
\text { - Register of special regime installations } \\
\text { - Register of pre-allocation of } \\
\text { remuneration } \\
\text { - Administrative record of electric } \\
\text { energy production } \\
\text { - Regulatory documents, especially } \\
\text { those issued by the Galician regional } \\
\text { administration }\end{array}$ & $\begin{array}{l}\text { - Temporary dynamics } \\
\text { concerning the } \\
\text { installation of wind } \\
\text { farms and MW } \\
\text { - Information on the } \\
\text { developers } \\
\text { - Information classified } \\
\text { according to the second } \\
\text { administrative phase }\end{array}$ & $\begin{array}{l}\text { - To understand the dynamics of } \\
\text { wind energy development in } \\
\text { relation to the legal framework } \\
\text { - To understand the future prospects } \\
\text { for the installation of new wind } \\
\text { farms and the creation of new } \\
\text { economic opportunities at the local } \\
\text { level }\end{array}$ \\
\hline 2. Economic & $\begin{array}{l}\text { - Statistical information on the electric } \\
\text { energy industry } \\
\text { - Statistical information on } \\
\text { special-regime energy sales } \\
\text { - Specialised reports published by } \\
\text { public and private entities }\end{array}$ & - Wind farm turnover & $\begin{array}{l}\text { - To measure the importance of this } \\
\text { new industrial activity in rural areas } \\
\text { - To estimate the turnover of wind } \\
\text { farms in order to compare it with } \\
\text { local revenues }\end{array}$ \\
\hline
\end{tabular}

Source: Own elaboration from the SIDWEG.

\subsection{Systematisation of the Information and Categories of Analysis}

From the information collected (Table 1) and the analysis of the regulatory framework, it was possible to identify the main sources of revenue, which were classified into two categories (Table 2): (i) income from conventional and specific taxes; and (ii) other incomes, which were obtained from the leasing of municipal land for the construction of wind farms and from the collaboration agreements drawn up between wind power firms and municipalities. Among these categories, there are two sources of revenue associated with the specific regulatory framework of Galicia [18]. The first one is a wind power tax (canon eólico) that partially benefits municipalities with wind farms in their territories. This wind power tax is a levy on the number of wind turbines, and it feeds the ECF [48]. Its taxable events are the negative visual, environmental, and other impacts of wind farm installations on the territory. The second specific source of income, i.e., singular wind farms, allows municipalities to 
promote wind power plants. The income flows for 2017, the last year for which there is information available, were estimated as follows. (i) Conventional taxes were calculated from the data of operating power collected in the SIDWEG and the updated average values obtained by Saladié [49] for Catalonia; (ii) ECF revenues were estimated from the systematisation of the municipal information published by the Official Journal of Galicia and reflected in the SIDWEG; (iii) The income derived from singular wind farms was calculated from information gathered from wind farm tenders and during the field work. This estimation allowed calculating the average annual income per MW, which were used to quantify the total revenues derived from singular wind farms in operation (SIDWEG); (iv) Finally, the data collected during the field work and systematised in the SIDWEG were also used to calculate the revenue obtained from the leasing of municipal land and from collaboration agreements.

Table 2. Comparative analysis of the categories of wind revenues in Galician municipalities.

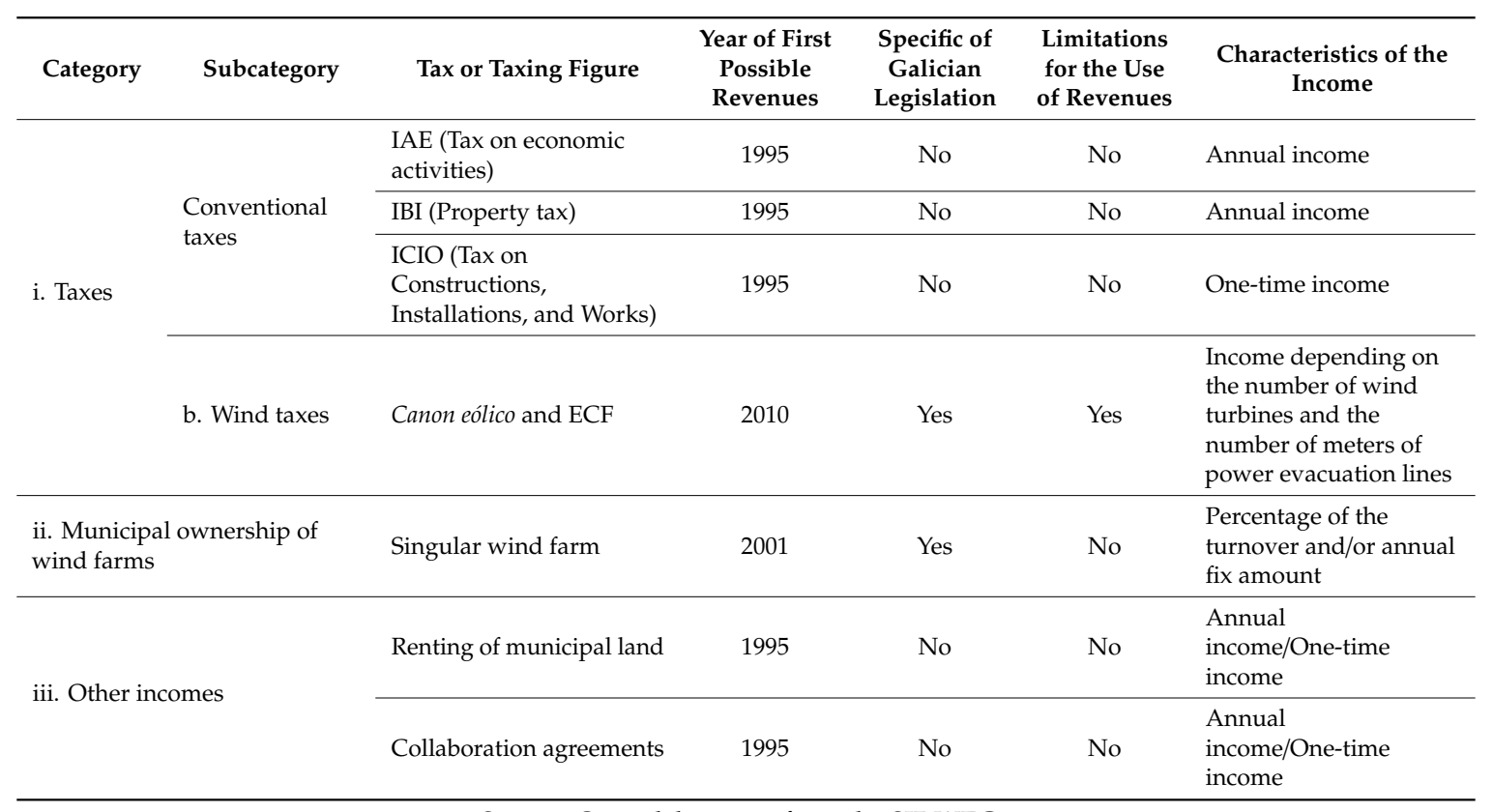

Source: Own elaboration from the SIDWEG.

\section{Results}

Figure 2 shows the temporal dynamics of the possibility of income flows for the municipalities during the period analysed. Thus, in 1997, with the installation of the first wind farms, conventional taxes started having a local economic impact. In 2001, the mechanism that allows developing small wind farms owned by the municipalities was established. The most recent regulatory change is connected to the creation of the wind power tax and the ECF in 2009. That was also the year in which the installed power levelled off; since then and until 2017, it has only increased by $3 \%$. In 2017, the total revenue of municipalities with wind farms in their territories amounted to 17.8 million euros (Table 3). The most important category of local income was that of taxes $(92.7 \%)$, followed by the municipal ownership of wind farms (7.0\%). The category of other incomes was the less significant one $(0.2 \%)$. In the following sections, each revenue category and subcategory will be analysed in detail. As shown in Figure 2, the rapid expansion of wind farms in Galicia has been favoured by the existence of incentives, which were mainly associated with feed-in tariff mechanisms [50]. However, this support model has greatly changed in the last few years. Thus, in 2013, the feed-in tariffs incentive system was eliminated, and new support mechanisms have been created since. On the one hand, there is an auction system in which the compensation-for-operation amounts are determined, and, on the other, there is a compensation-for-investment mechanism [51]. The halt in the expansion of wind farms observed since 2008 was not a consequence of the establishment of specific taxes such as the canon 
eólico, but rather of other factors mainly including legal uncertainty, elimination of the compensation schemes, and decline of the demand because of the crisis.
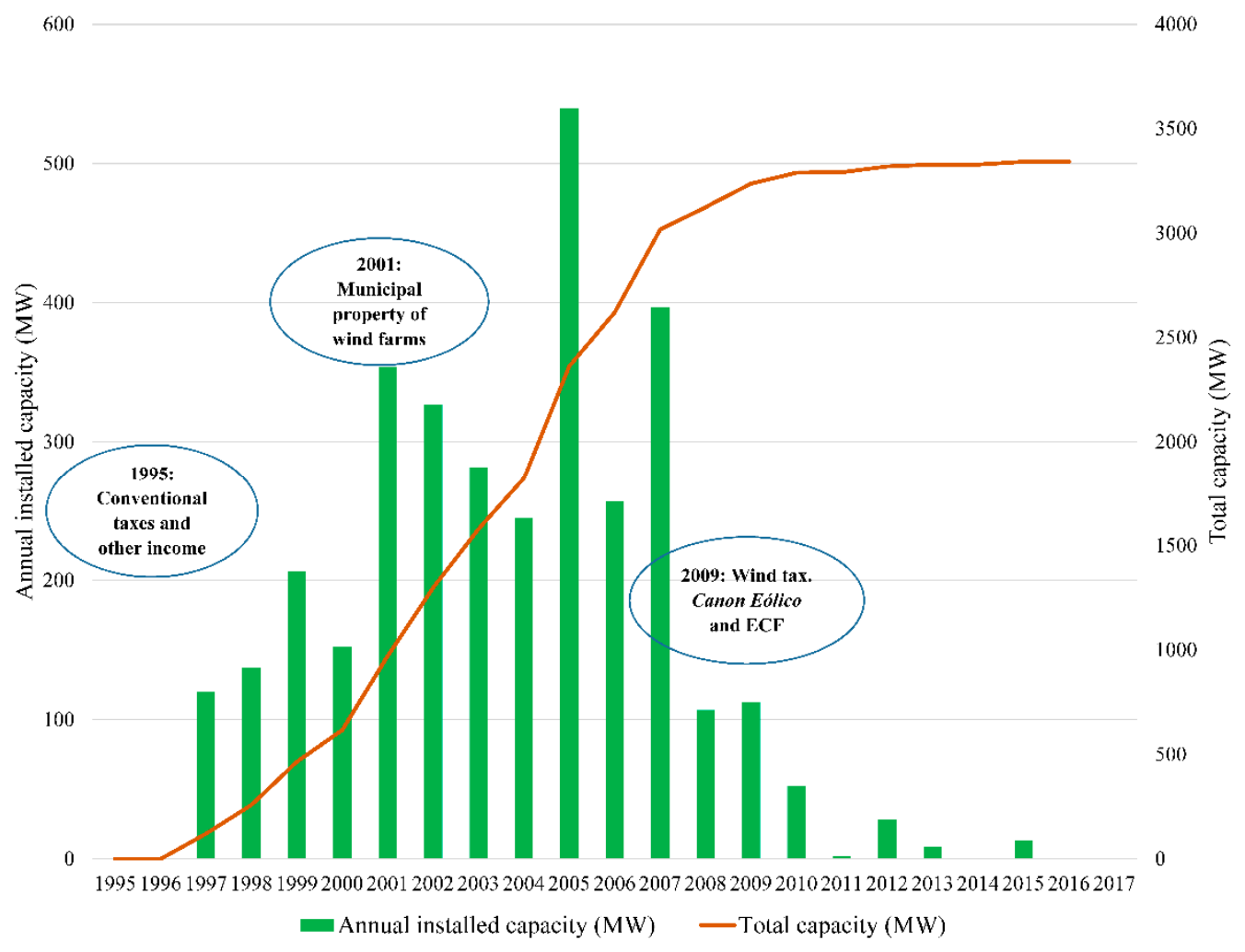

Figure 2. Temporal dynamics of the possibility of income flows for municipalities in the process of developing wind farms in Galicia (MW). Source: Own elaboration from the SIDWEG.

Table 3. Characterisation and estimation of revenues for Galician municipalities with wind farms according to the income flow (2017).

\begin{tabular}{|c|c|c|c|c|c|}
\hline Category & Subcategory & Tax/Mechanism & $\begin{array}{c}\text { Number of } \\
\text { Municipalities }\end{array}$ & $\begin{array}{c}\text { Income (1000 } \\
€)\end{array}$ & Income $(\%)$ \\
\hline \multirow{3}{*}{ i. Taxes } & \multirow{2}{*}{ a. Conventional taxes $\left(^{*}\right)$} & IBI & 107 & 6719 & 37.7 \\
\hline & & IAE & 103 & 3499 & 19.6 \\
\hline & b. Wind taxes & Canon eólico and ECF & $117^{(* *)}$ & 6307 & 35.4 \\
\hline ii. Municipal o & nership of wind farms & Singular wind farm & 13 & 1255 & 7.0 \\
\hline \multirow{2}{*}{\multicolumn{2}{|c|}{ iii. Other incomes }} & Renting of municipal land & 5 & $<20$ & 0.1 \\
\hline & & Collaboration agreements & 3 & $<20$ & 0.1 \\
\hline \multicolumn{3}{|c|}{ Total income estimation } & & 17,820 & 100 \\
\hline
\end{tabular}

Source: Own elaboration from the SIDWEG. Notes: $\left(^{*}\right)$ The ICIO is not taken into consideration because it is only paid once, with the construction of the wind farm (no new farms were installed in 2017); $(* *)$ This tax includes municipalities with power evacuation lines, in addition to the 107 municipalities with wind turbines in their territories.

\subsection{Municipal Tax Revenues}

\subsubsection{Conventional Taxes}

The wind energy model established in Galicia is based almost exclusively on the installation of wind farms promoted by private companies. The development of this business activity requires the payment of taxes to the local administration that become a source of income for the territories where the wind farms are located. In particular, there are three conventional taxes positively affecting those municipalities: the tax on economic activities (IAE), the property tax (IBI), and the tax on constructions, 
installations, and works (ICIO). The first two taxes are annually paid, while the third one is paid only once, with the construction of the wind farm. Among these three taxes, the IBI is the most important one (37.7\% of the total tax revenue in 2017). This tax changed substantially after 2007 as a result of a judicial process initiated by the Galician Federation of Municipalities and Provinces. This process determined that wind farms belong to a specific category of taxable goods (BICES), on which higher tax rates are imposed. Tax rates for BICES are set by municipalities through a tax ordinance and amount to between $0.4-1.3 \%$ of the cadastral value of the property.

The IAE is another annual tax managed by the municipalities (19.6\% of the total revenue in 2017). It is a levy on the wind power activity that imposes a rate per unit of power. Wind farms with a turnover of less than 1 million euros per year are exempt from this tax. The taxable base is linked to the net annual turnover, and the tax rate is around 1.5\% [52]. Finally, the ICIO has also generated, within the wind industry, some legal disputes regarding the rates to be paid [53]. The debate revolved around whether the cost of wind turbines ought to be included in the taxable base of the ICIO or not. Various court sentences have been clear on the matter, and have included the cost in the taxable base. As a result, there has been an increase of income flow for the municipalities, given that wind turbines account for $70 \%$ of the cost of a wind farm [54]. The municipality establishes the ICIO rate, which ranges between $2-4 \%$ of the cost of executing the works, and is only paid once.

\subsubsection{Specific Taxes: the canon eólico and the Environmental Compensation Fund}

The canon eólico was created in 2009 by the Galician regional government for the purpose of taxing negative externalities associated with the installation of wind farms. More specifically, this levy taxes the number of wind turbines and establishes a tax-exempt tax bracket and three other tax brackets with rates that increase with the number of wind turbines (see Table 4). Due to the quick development of wind energy in Galicia, the unit capacity of wind turbines is generally limited, which implies the installation of a high number of wind turbines per wind farm. Thus, most plants (65\%) fall within the highest tax bracket, which accumulates $94.6 \%$ of the income collected through this tax. The canon eólico feeds the ECF, which distributes a significant part of its income to the municipalities affected by wind farms. These income flows are channelled as non-competitive subsidies, and therefore are not freely disposable. They are intended to implement actions related to production, employment generation, biodiversity conservation, the recreational use of natural resources, and the sustainable use of renewable energies [48].

Table 4. Characterisation and estimation of incomes derived from the canon eólico in Galicia (2017).

\begin{tabular}{lccccc}
\hline $\begin{array}{c}\text { Canon eólico Tax } \\
\text { Bracket (No. of } \\
\text { Wind Turbines) }\end{array}$ & $\begin{array}{c}\boldsymbol{\epsilon} \text { per Wind } \\
\text { Turbine-Year }\end{array}$ & $\begin{array}{c}\text { No. of Wind } \\
\text { Farms }\end{array}$ & $\begin{array}{c}\text { No. of Wind } \\
\text { Turbines }\end{array}$ & $\begin{array}{c}\text { Income } \\
(\mathbf{1 0 0 0} \text { euros) }\end{array}$ & Income (\%) \\
\hline Between 1-3 & 0 & 19 & 33 & 0 & 0 \\
Between 4-7 & 2300 & 11 & 58 & 133 & 4.9 \\
Between 8-15 & 4100 & 23 & 275 & 21,954 & 94.6 \\
More than 15 & 5900 & 101 & 3721 & 23,215 \\
\hline Total & Source: Own elaboration from the SIDWEG. & 4087
\end{tabular}

After the canon eólico came into force, the total revenue collected through this new wind tax was estimated at around 22 million euros per year. This amount feeds the ECF, and the Galician regional government, which is responsible for managing this tax, determines that around one-third of those revenues (between 6-8 million euros per year) will go directly to the municipalities that have wind farms installed in their territories. In other words, the municipalities receive an income in the form of non-competitive subsidies according to the number of wind turbines and the metres of power evacuation lines in their territories. In the last years, ECF revenues have decreased (Figure 3), which has been mainly due to changes in the amounts allocated by the Galician government, and to a lesser 
extent, the reduction in the number of wind turbines caused by the repowering of wind farms [55]. In relation to the drop in EFC revenues allocated to municipalities with wind farms in their territories, there is no information on the reasons behind the regional government's reduction of the amounts in the last few years. In spite of this, it is worth highlighting that during the nine years in which the tax has been in force, the municipalities with wind farms and evacuation lines have received more than 63 million euros.

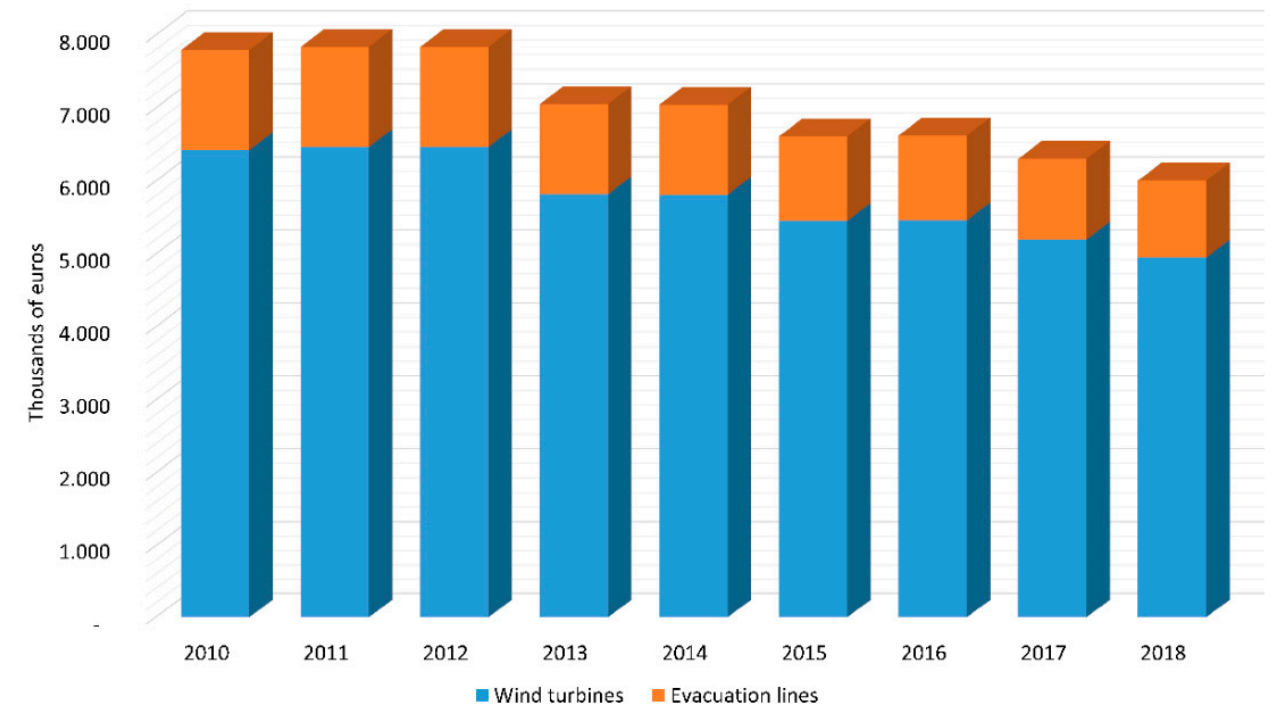

Figure 3. ECF non-competitive subsidies for municipalities with wind turbines and evacuation lines in their territories (thousands of euros). Source: Own elaboration from the SIDWEG.

With regard to the revenues from the canon eólico feeding the ECF, the Galician government has annually allocated, through competitive calls for proposals, between 1.3-2.8 million euros to environmental action programs to be developed in the municipalities. The use made of the remaining approximately 14 million euros is unknown, since there is no public information provided by the regional government regarding the management of these resources.

In 2017, the direct ECF revenues earned by municipalities with wind farms were estimated at 6.3 million euros, representing $35.4 \%$ of the total municipal incomes derived from wind power activity. From a geographical perspective, the Galician municipalities that received greater amounts from this tax were the smaller ones, which are dispersed across the region's territory (Figure 4). The economic impact of this tax on the municipalities located in the area of Serra do Xistral is worth highlighting, and among them, the case of Muras in particular, where 381 wind turbines are currently in operation. This municipality, which had a budget of about 1.7 million euros in 2016, has received, in the period during which the ECF has been active (2010-2018), more than 5.3 million euros in non-competitive subsidies for the number of wind turbines and evacuation lines located in its territory. 


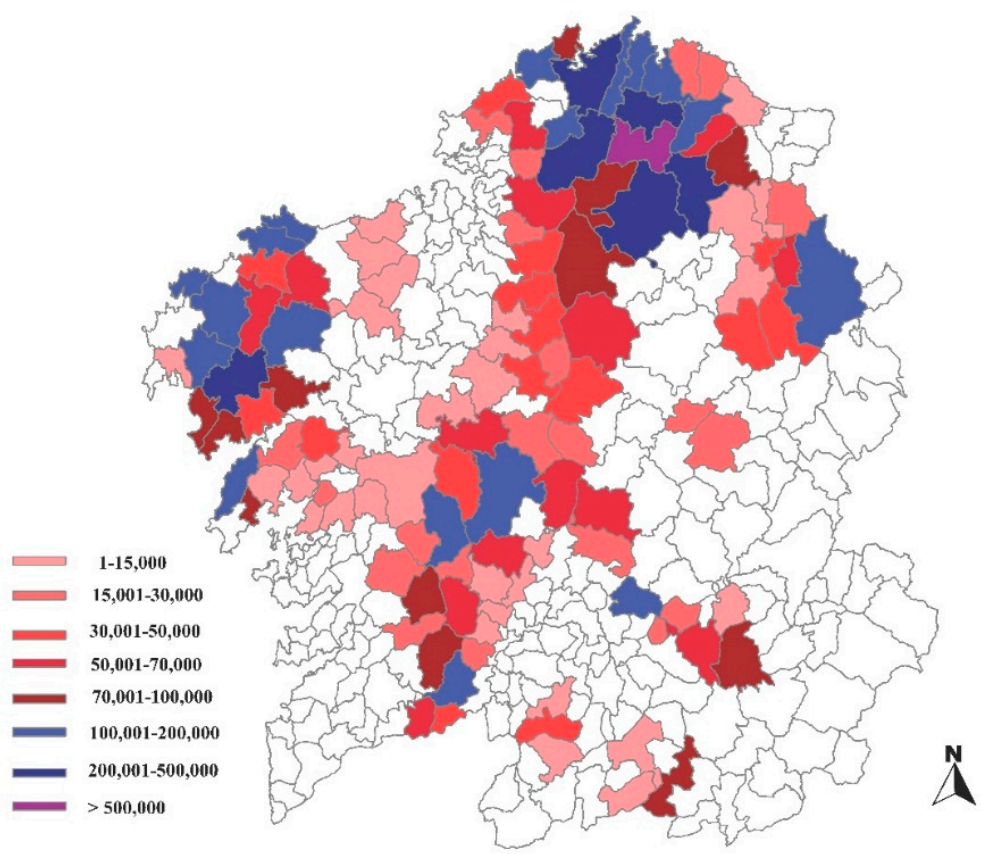

Figure 4. Geographical characterisation of ECF revenues for Galician municipalities with wind farms in their territories (2015) (euros). Source: Own elaboration from the SIDWEG.

\subsection{Municipal Ownership of Wind Farms: Singular Wind Farms}

In 2001, the specific category of singular wind farms was created to allow municipalities to promote this kind of installation. The capacity of each singular wind farm was limited to a maximum of $3 \mathrm{MW}$, which is a restriction that conditioned the generation of local revenues. Initially, the installation of this type of wind farm attracted the interest of many Galician municipalities. Up to 182 of the 315 municipalities in the region requested permits to build their own wind farms. However, this specific type of wind farm did not achieve the expected degree of development. Their limited expansion, despite the great interest they initially attracted among local governments, is mainly related to the legal uncertainty of the various calls for tenders. This uncertainty caused the cancellation of the largest call for tenders for this type of wind farm, and led to several subsequent court sentences that have paralysed the setting up of these singular wind plants [56].

The monitoring data of the administrative proceedings to install this type of wind farm indicate that in 2018, barely 13 of them were in operation (Figure 5). These wind farms have an aggregated installed capacity of $34.80 \mathrm{MW}$, which stands for only $1 \%$ of the total operating capacity.

Once the administrative authorisation is obtained, these farms can be managed through various mechanisms: (a) with the municipality' own resources; (b) by creating a joint venture controlled by the municipality; or (c) by issuing a call for tenders ending in an administrative concession to a company that will manage the wind farm. In Galicia, all the singular wind farms in operation were tendered by the local administration. From the information gathered and synthesised in the SIDWEG, it is possible to estimate the income per MW in operation earned by the municipalities. Thus, in 2017, the revenues per singular wind farm were estimated at between 19,000-47,000 euros per MW [56], with an average annual provision of 36,000 euros per MW, which is a small amount when compared to other sources of income. Thus, singular wind farms in Galicia contributed 1.2 million euros to local revenues ( $7 \%$ of the total). The collection and analysis of municipal wind farm tenders shows that the income flows usually combine an annual payment as a percentage of the wind farm's turnover (sometimes reaching $20 \%$ ), and a fixed annual payment per installed capacity. Finally, it is worth mentioning that several singular wind farms awaiting administrative processing and not yet in operation are managed by joint ventures that will be interesting to observe in the near future, although at the moment it is not possible to compare the benefits of this mechanism with those of public tenders. 


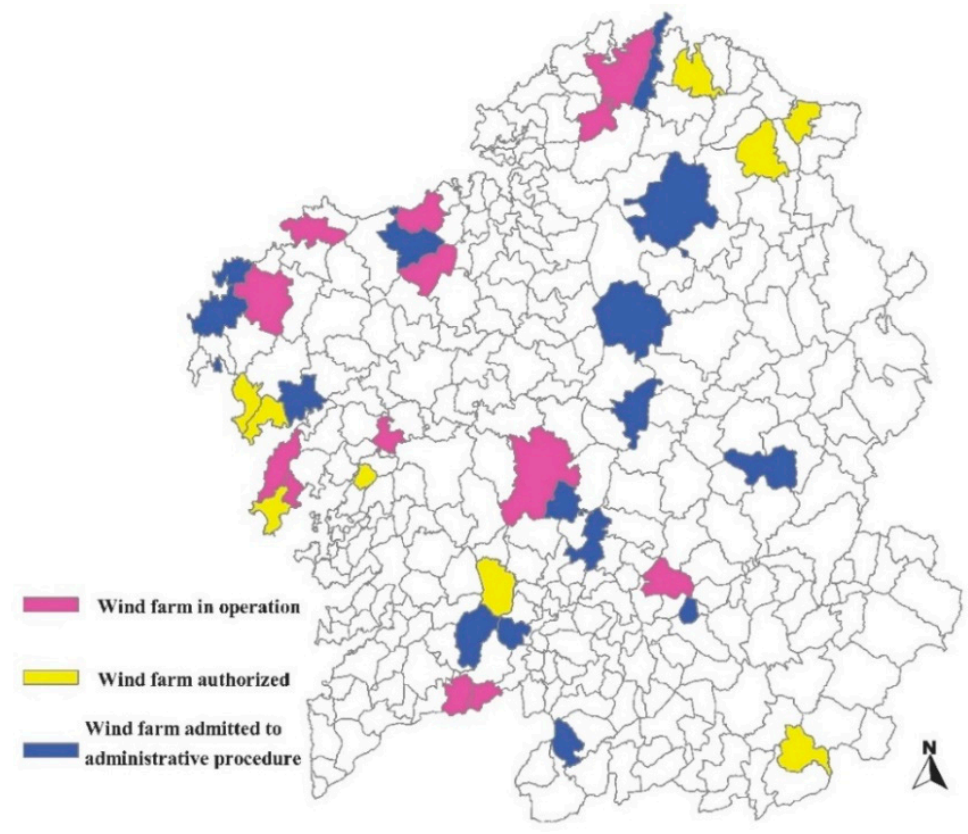

Figure 5. Geographical characterisation of municipally owned singular wind farms in Galicia (September 2018). Source: Own elaboration from the SIDWEG.

\subsection{Other Incomes}

This research work has identified two other wind-related income flows for local administrations, which nevertheless have little relevance on the total revenue $(0.2 \%)$. The first source of income is linked to the signing of collaboration agreements between promoters and municipalities, which include the annual payment of some monetary amounts. For instance, the municipality of Cuntis signed an agreement with the company that developed the Monte Arca wind farm for the creation and maintenance of a new hiking trail. The agreement disaggregated the works to be implemented and the corresponding monetary amounts. In other countries, these income flows associated with specific agreements were framed within the concept of community benefits that are voluntarily provided by the promoters [57]. For instance, they are common in England, where they can be managed by local governments or social entities [31]. A second mechanism to obtain revenues for the local administration is to rent land belonging to the municipality for the installation of wind farms. However, in the case of Galicia, only $2 \%$ of the forest areas where the wind farms are usually located are municipally owned [58]. Consequently, only a few municipalities receive income via land leasing, according to the information available in the SIDWEG.

\section{Discussion}

\subsection{Wind Revenues and Rural Development in Galicia}

In the case of Galicia, wind power activity has created an important flow of direct income for the municipalities. If the estimated income earned by municipalities with wind farms in their territories in 2017 (17.8 million euros) is compared with the estimated turnover of the wind farms that same year, it is possible to observe how those revenues represent $3.17 \%$ of the estimated turnover of the wind farms. This percentage is relatively low, especially when considering the case of Greece, where local administrations collect the same percentage through only one tax (see Dimitropoulos and Kontoleon [24]). However, as underlined by Slattery et al., [10], these new sources of income gain further significance since the wind farms are installed in rural areas with little economic activity and important social and environmental problems. Thus, the revenues derived from wind power activity can be used to improve public services and/or the capacity of investment of the local economic network, 
as well as to implement activities linked to rural development and sustainability, as in Mexico [59] or Oklahoma [32].

As analysed before, taxes are the main direct wind revenue obtained by Galician municipalities; therefore, they present an opportunity to encourage local development through public expenditure [31]. However, in the case of incomes collected via conventional taxes (57.3\% of the total in 2017), it is extremely difficult to identify which has been their final use due to at least two reasons: (a) tax conditions have changed during the period analysed, and (b) there is no disaggregated public information on the matter. In this sense, it is possible to affirm that wind power activity contributes to the economic growth of the affected areas, but it is not possible to determine with certainty the effects that it has on their rural development. In other regions, it has been proven that wind farms facilitate the maintenance of the provision of basic services for the population [32,33], and contribute to production diversification and the viability of agricultural activities [60]. In the case of Galicia, a singular example found in the SIDWEG is that of the municipality of Muras, which, ever since 2016, has allocated part of its wind revenues to helping local families pay their electricity bill.

On the other hand, ECF revenues (35.4\% of the total in 2017) can be more easily monitored due to the limitations established in their regulatory framework. Thus, the financing of fire prevention, sanitation, improvement of infrastructures, and other environmental works and actions with ECF revenues is quite common. These expenditure policies foster the generation of economic activities and the creation of employment in rural municipalities with wind farms installed in their territories. For instance, in 2017, staff was hired with ECF revenues in the municipalities of Cedeira (seven workers), Ponteceso (nine workers), Aranga (eight workers), Cariño (two workers), and Muras (10 workers). These experiences prove that although municipalities are only granted a limited share of the amounts collected through the specific wind power tax (canon eólico), local revenues may be used to revive local employment and other economic activities in rural areas. If the taxes were directly controlled by the municipalities or if the amounts allocated were larger, the impact and the potential for revitalisation would notably increase, which would be of great relevance in the problematic context of these rural municipalities.

\subsection{Regulatory Limitations to the Access, Control, and Generation of Wind Revenues}

The opportunities, conditions, and barriers to local income generation greatly depend on the public policies that define and limit the spheres and possibilities [61]. In this sense, the analysis of the Galician regulatory framework shows how the current legislation has negatively conditioned the results obtained at a local level. First of all, it is necessary to bring into focus the limitations and barriers to entry imposed on the decision-making capacity of local administrations with regard to the planning and authorisation of wind farms. In contrast, the development of wind farms by a few private companies with few or no ties to the territory where the activity is being developed has been favoured, thus conditioning their local economic impacts [21]. Galician municipalities have witnessed the construction of wind farms in their own territories without actually having a say in the process. This situation is different in regions where there are governance processes associated with the installation of wind farms [45]. Thus, for instance, in the United States, local authorities have a crucial role in the planning and development of regulations, and they sometimes even decide the location of the wind farms [43]. In Sweden, they even have veto power over wind farm projects [44]. In line with what Fast and Mabee pointed out [60], the weakening of the decision-making capacity of Galician municipalities has taken away all the structural incentives for companies to negotiate with them.

Moreover, the regulatory framework has restricted the possibilities of building and managing municipally owned wind farms. This circumstance also makes the case of Galicia different from those of other regions where local ownership seems to be a relevant option [27]. In Denmark, for instance, cooperatives run by the local population control a great number of wind turbines $(15 \%)$, while in Germany, community ownership is estimated at $20 \%$ [28]. From the information gathered in the SIDWEG, it is possible to observe how singular wind farms, which is the only category that allows 
local ownership, represented only $1 \%$ of the total operating capacity in 2017. Despite the initial interest awakened by this specific type of wind farm, the restrictions imposed on its capacity and the low degree of its development have resulted in a very limited income collection and a very low impact on the total revenue [56]. Thus, $3 \mathrm{MW}$ per singular wind farm is a very low capacity considering the size of most farms in Galicia, the capacity of which is, in many cases, close to $50 \mathrm{MW}$; consequently, the farms' turnover and their positive impact at a local level are also conditioned by this limitation.

Third, the specific wind tax (canon eólico) associated with the ECF is levied on the number of wind turbines, which is in contrast with other compensation funds levied on the installed capacity, such as the one created in the region of Valencia (Spain), or on the plant's turnover, as in Greece [24] or Portugal [25]. In Galicia, this connection to the number of wind turbines puts the very logic of the tax and the ECF at stake. In theory, the ECF was designed to compensate for the negative environmental externalities generated by wind farms [62]. However, the definition of the tax, which is articulated into several tax brackets, hinders its own objectives. For instance, a wind farm with only three turbines built in an area where there were no previous installations would be exempt from paying the tax, despite the negative visual environmental impact that it would have on that specific geographical area [63]. In addition, the current repowering of Galician wind farms [64] is reducing the number of turbines, and consequently, the revenues derived from the ECF. One of the objectives of the canon eólico is to incentivise the repowering of wind farms by reducing the amounts to be paid if a large number of wind turbines with a low unit capacity are substituted by a smaller number of turbines with a higher unit capacity, or even by establishing an exempted bracket.

Both the design of the canon eólico, under non-local control, and the allocation of ECF revenues established by the Galician government reduce the economic impact of this tax on rural municipalities. The limited local impact is underlined by only between $26-36 \%$ of the 22 million euros that are annually collected, on average, through this specific wind tax benefiting the municipalities affected by wind farms. The analysis herein performed shows how, despite the creation of specific taxes, mechanisms, or categories such as the ECF or singular wind farms, the main revenue of municipalities with wind farms still comes from conventional taxes. These results confirm the shortcomings of specifically designed wind taxes and the need to advance in the development of public policies aiming at increasing the possibilities for economic and rural development in the municipalities where wind farms are built.

\subsection{Limitations and Future Research Prospects}

The absence of a public taxpayer register for wind-farming activities limits the availability of information about the wind revenues earned by the municipalities. Although we have tried to overcome this limitation through indirect calculations, future research works should aim at compiling in greater detail and at a higher level of disaggregation the amounts of local revenue derived from the development of wind farms. Hopefully, the regional government will also improve the level of transparency in the management of the wind power industry, which would allow arriving at more solid conclusions regarding the above-mentioned and currently lacking information about the destination of two-thirds of the annual revenues collected from the canon eólico. On the other hand, it will be interesting to address other issues related to the present research work, such as verifying whether the improvement of this industrial sector and of other services linked to wind power production generates any spillovers that may foster local development, as indicated in other works $[65,66]$. Investigating the role that local economic impact plays in the local processes of approval of wind farms in rural areas of Galicia will be another worthwhile line of research.

\section{Conclusions and Policy Recommendations}

The research work developed around the SIDWEG has allowed the identification and quantification of the direct local economic impacts of wind power activity in the rural municipalities of Galicia. Thus, several sources of local income have been identified: the taxation of wind farms through conventional taxes and through the ECF, the municipal ownership of wind farms, the leasing of municipal land 
to wind farm promoters, and the collaboration agreements drawn up between companies and municipalities. The income flows of municipalities with wind farms in their territories has been quantified as 17.8 million euros for 2017.

The main sources of local income are the IBI (37.7\% in 2017) and the specific wind tax (canon eólico) (35.4\%), followed by the IAE (19.6\%) and the revenues from municipally owned wind farms $(7.0 \%)$. In this sense, the present work shows how the public policies implemented have, through the regulatory framework, limited and conditioned the possibilities for increasing local revenues derived from wind power activity. The possibility of promoting municipally owned wind plants is only possible through the installation of singular wind farms. This option has been poorly developed, and proves to be very limiting in terms of installed capacity. The specific wind tax (canon eólico) and the ECF have a great potential to encourage local development through employment creation and the promotion of environmentally sustainable economic activities. However, the lack of control that local administrations have over these mechanisms and the limited amount of revenue (only around 30\%) that is transferred to the municipalities reduces their potential. In brief, it is possible to affirm that wind power activity allows increasing local revenues, though limitedly, and that consequently, there is a need to continue researching the extent to which these new sources of income contribute to the sustainable development of rural municipalities beyond their economic growth.

Finally, considering our results and the currently intense relaunching of the wind power sector in Galicia, we include the following policy recommendations. First of all, our results make clear that, as pointed out in the literature [21], the restricted local ownership of wind farms and the limited negotiating capacity on the part of local authorities reduces the possible benefits and positive impacts of this activity. Therefore, it would be reasonable to implement a new policy aimed at increasing local ownership of renewable energy plants. This could be done through the relaunching of singular wind farms, eliminating the $3 \mathrm{MW}$ per farm limitation, or through the design of a new mechanism that would favour the setting up of new locally owned wind plants. Secondly, understanding that taxes on wind power production may generate opportunities to encourage local development through public expenditure [31] and given the existence of a specific tax in Galicia (canon eólico), it would also be positive to hand over the total control over this tax to the local authorities in order to better support local projects of transformation, thus improving as well the level of energy justice [67] derived from progress in renewable energies.

Thirdly, it might be relevant to grant a binding decision-making capacity to the local governments in order to incentivise negotiation with power-promoting companies [60]. This would foster the drawing up of collaboration agreements between promoters and municipalities, which are common in other regions [57], and would lead to an increase of local revenues. These measures would not hinder the development of the wind power industry (many of them are still in force in countries such as Denmark or Germany [28], where wind power production is most extended), and would instead allow an increment of income flows for Galician rural municipalities, which in turn would facilitate the implementation of other measures favouring local development in a context of serious structural problems, including depopulation, a lack of employment opportunities, and environmental challenges such as forest fires.

Author Contributions: D.C. and X.S. designed the research plan and carried out the field work. D.C. systematised and estimated the collected data. D.C., X.S. and D.P.-N. analysed and discussed the results. D.C., D.P.-N. and X.S. jointly wrote the article. X.S. directed the research work.

Funding: This research received no external funding.

Conflicts of Interest: The authors declare no conflict of interest. 


\section{References and Notes}

1. Intergovernmental Panel on Climate Change (IPCC). Summary for Policymakers; Edenhofer, O., Pichs-Madruga, R., Sokona, Y., Eds.; IPCC Special Report on Renewable Energy Sources and Climate Change Mitigation; Cambridge University Press: Cambridge, UK, 2011.

2. European Parliament. Directive 2009/28/EC of the European Parliament and of the Council, of 23 April 2009, on the Promotion of the Use of Energy from Renewable Sources and Amending and Subsequently Repealing Directives 2001/77/EC and 2003/30/EC. 2009. Available online: http://eur-lex.europa.eu/legal-content/EN/ ALL/?uri=CELEX:32009L0028 (accessed on 20 November 2018).

3. Ertay, T.; Kahraman, C.; Kaya, İ. Evaluation of renewable energy alternatives using MACBETH and fuzzy AHP multicriteria methods: The case of Turkey. Technol. Econ. Dev. Econ. 2013, 19, 38-62. [CrossRef]

4. Kaplan, Y.A. Overview of wind energy in the world and assessment of current wind energy policies in Turkey. Renew. Sustain. Energy Rev. 2015, 43, 562-568. [CrossRef]

5. Michalak, P.; Zimny, J. Wind energy development in the world, Europe and Poland from 1995 to 2009. Current status and future perspectives. Renew. Sustain. Energy Rev. 2011, 15, 2330-2341. [CrossRef]

6. Kemmoku, Y.; Keiko, N.; Kawamoto, T.; Sakakibara, T. Life cycle $\mathrm{CO}_{2}$ emissions of a photovoltaic/wind/diesel generating system. Electr. Eng. Jpn. 2002, 138, 14-23. [CrossRef]

7. Kayser, B. The future of the countryside. In Beyond Modernization: The Impact of Endogenous Development; van der Ploeg, J.D., Van Dijk, G., Eds.; Van Gorcum: Assen, Holland, 1995; pp. 179-190.

8. Ryser, L.; Halseth, G. Rural Economic Development: A Review of the Literature from Industrialized Economies. Geogr. Compass 2010, 4, 510-531. [CrossRef]

9. Varela-Vázquez, P.; Sánchez-Carreira, M.C. Socioeconomic impact of wind energy on peripheral regions. Renew. Sustain. Energy Rev. 2015, 50, 982-990. [CrossRef]

10. Slattery, M.C.; Lantz, E.; Johnson, B.L. State and local economic impacts from wind energy projects: Texas case study. Energy Policy 2011, 39, 7930-7940. [CrossRef]

11. Aceleanu, M.I.; Șerban, A.C.; Tîrcă, D.M.; Badea, L. The rural sustainable development through renewable energy. The case of Romania. Technol. Econ. Dev. Econ. 2018, 24, 1408-1434. [CrossRef]

12. Fouché, E.; Brent, A. Journey towards Renewable Energy for Sustainable Development at the Local Government Level: The Case of Hessequa Municipality in South Africa. Sustainability 2019, 11, 755. [CrossRef]

13. Benedek, J.; Sebestyén, T.; Bartók, B. Evaluation of renewable energy sources in peripheral areas and renewable energy-based rural development. Renew. Sustain. Energy Rev. 2018, 90, 516-535. [CrossRef]

14. Instituto Nacional de Estadística-INE. Indicadores de Estructura de la Población. Madrid. 2018. Available online: http://www.ine.es (accessed on 20 November 2018).

15. Instituto Galego de Estatística-IGE. Nomenclator. Santiago de Compostela. 2018. Available online: https://www.ige.eu (accessed on 20 November 2018).

16. Corbelle, E.; Crecente, R.O. Abandono de terras: Concepto teórico e consecuencias. Revista Galega de Economía 2008, 17, 47-62.

17. Fuentes-Santos, I.; Marey-Pérez, M.F.; González-Manteiga, W. Forest fire spatial pattern analysis in Galicia (NW Spain). J. Environ. Manag. 2013, 128, 30-42. [CrossRef] [PubMed]

18. Copena, D. Enerxía Eólica e Medio Rural: Unha Análise Aplicada dos Impactos Socioeconómicos dos Parques Eólicos no Mundo Rural Galego. Ph.D. Thesis, Universidade de Vigo, Vigo, Spain, 17 December 2015. Available online: http://www.investigo.biblioteca.uvigo.es/xmlui/handle/11093/658 (accessed on 16 April 2017).

19. Instituto Galego de Estatística-IGE. Poboación, Entidades e Densidade. Santiago de Compostela. 2017. Available online: https://www.ige.eu (accessed on 12 April 2018).

20. Copena, D.; Simón, X. Wind farms and payments to landowners: Opportunities for rural development for the case of Galicia. Renew. Sustain. Energy Rev. 2018, 95, 38-47. [CrossRef]

21. Delicado, A.; Figueiredo, E.; Silva, L. Community perceptions of renewable energies in Portugal: Impacts on environment, landscape and local development. Energy Res. Soc. Sci. 2016, 13, 84-93. [CrossRef]

22. Rand, J.; Hoen, B. Thirty years of North American wind energy acceptance research: What have we learned? Energy Res. Soc. Sci. 2017, 29, 135-148. [CrossRef] 
23. Baxter, J.; Morzaria, R.; Hirsch, R. A case-control study of support/opposition to wind turbines: Perceptions of health risk, economic benefits, and community conflict. Energy Policy 2013, 61, 931-943. [CrossRef]

24. Dimitropoulos, A.; Kontoleon, A. Assessing the determinants of local acceptability of wind-farm investment: A choice experiment in the Greek Aegean Islands. Energy Policy 2009, 37, 1842-1854. [CrossRef]

25. Nadaï, A.; Krauss, W.; Afonso, A.I.; Dracklé, D.; Hinkelbein, O.; Labussière, O.; Mendes, C. El paisaje y la transición energética: Comparando el surgimiento de paisajes de energía eólica en Francia, Alemania y Portugal. Nimbus 2010, 25-26, 155-173.

26. Nolden, C. Governing community energy-Feed-in tariffs and the development of community wind energy schemes in the United Kingdom and Germany. Energy Policy 2013, 63, 543-552. [CrossRef]

27. Yin, Y. An analysis of empirical cases of community wind in Oregon. Renew. Sustain. Energy Rev. 2013, 17, 54-73. [CrossRef]

28. Bauwens, T.; Gotchev, B.; Holstenkamp, L. What drives the development of community energy in Europe? The case of wind power cooperatives. Energy Res. Soc. Sci. 2016, 13, 136-147. [CrossRef]

29. Del Río, P.; Burguillo, M. An empirical analysis of the impact of renewable energy deployment on local sustainability. Renew. Sustain. Energy Rev. 2009, 13, 1314-1325. [CrossRef]

30. Paolo De Pascali, P.; Bagaini, A. Energy Transition and Urban Planning for Local Development. A Critical Review of the Evolution of Integrated Spatial and Energy Planning. Energies 2019, 12, 35. [CrossRef]

31. Munday, M.; Bristow, G.; Cowell, R. Wind farms in rural areas: How far do community benefits from wind farms represent a local economic development opportunity? J. Rural Stud. 2011, 27, 1-12. [CrossRef]

32. Castleberry, B.; Greene, J.S. Impacts of wind power development on Oklahoma's public schools. Energy Sustain. Soc. 2017, 7. [CrossRef]

33. Okkonen, L.; Lehtonen, O. Socio-economic impacts of community wind power projects in Northern Scotland. Renew. Energy 2016, 85, 826-833. [CrossRef]

34. Liebe, U.; Bartczak, A.; Meyerhoff, J. A turbine is not only a turbine: The role of social context and fairness characteristics for the local acceptance of wind power. Energy Policy 2017, 107, 300-308. [CrossRef]

35. Slattery, M.C.; Johnson, B.L.; Swofford, J.A.; Pasqualetti, M.J. The predominance of economic development in the support for large-scale wind farms in the U.S. Great Plains. Renew. Sustain. Energy Rev. 2012, 16, 3690-3701. [CrossRef]

36. Jami, A.A.N.; Walsh, P.R. The role of public participation in identifying stakeholder synergies in wind power project development: The case study of Ontario, Canada. Renew. Energy 2014, 68, 194-202. [CrossRef]

37. Mundaca, L.; Busch, H.; Schwer, S. 'Successful' low-carbon energy transitions at the community level? An energy justice perspective. Appl. Energy 2018, 218, 292-303. [CrossRef]

38. Upham, P.; García, J. A cognitive mapping approach to understanding public objection to energy infrastructure: The case of wind power in Galicia, Spain. Renew. Energy 2015, 83, 587-596. [CrossRef]

39. Breukers, S.; Wolsink, M. Wind power implementation in changing institutional landscapes: An international comparison. Energy Policy 2007, 35, 2737-2750. [CrossRef]

40. Johansen, K.; Emborg, J. Wind farm acceptance for sale? Evidence from the Danish wind farm co-ownership scheme. Energy Policy 2018, 117, 413-422. [CrossRef]

41. Krog, L.; Sperling, K.; Lund, H. Barriers and Recommendations to Innovative Ownership Models for Wind Power. Energies 2018, 11, 2602. [CrossRef]

42. Nadaï, A. "Planning", "siting" and the local acceptance of wind power: Some lessons from the French case. Energy Policy 2007, 35, 2715-2726. [CrossRef]

43. Jacquet, J.B. Landowner attitudes toward natural gas and wind farm development in northern Pennsylvania. Energy Policy 2012, 50, 677-688. [CrossRef]

44. Söderholm, P.; Ek, K.; Pettersson, M. Wind power development in Sweden: Global policies and local obstacles. Renew. Sustain. Energy Rev. 2007, 11, 365-400. [CrossRef]

45. Smith, A. Emerging in between: The multi-level governance of renewable energy in the English regions. Energy Policy 2007, 35, 6266-6280. [CrossRef]

46. Cassell, C.; Symon, G. Essential Guide to Qualitative Methods in Organizational Research; Sage Publications: London, UK, 2004; pp. 154-164.

47. McKim, C.A. The value of mixed methods research: A mixed methods study. J. Mix Methods Res. 2015, 11, 202-222. [CrossRef] 
48. Presidencia. Lei 8/2009, do 22 de Decembro, pola que se Regula o Aproveitamento Eólico en Galicia e se Crean o canon Eólico e o Fondo de Compensación Ambiental; Diario Oficial de Galicia de 29 de decembro de 2009; Xunta de Galicia: Santiago de Compostela, España, 2009.

49. Saladié, S. Impacte econòmic de les centrals eòliques en els pressupostos municipals a Catalunya; Associació de Municipis Eòlics de Catalunya: La Granadella, Spain, 2014.

50. Iglesias, G.; del Río, P.; Dopico, J.A. Policy analysis of authorization procedures for wind energy deployment in Spain. Energy Policy 2011, 39, 4067-4076. [CrossRef]

51. The compensation for the generation of MWh by wind farms has changed during the expansion of the wind power industry. These changes have been implemented through various regulations. At the beginning of the wind power boom, the selling price of wind energy was fixed in relation to the electricity tariffs and the capacity installed, in addition to other complements. Later on, in 1998, a premium was introduced, the amount of which depended on various factors. After 2004, an incentive was created, in addition to the premium, for participation in the market; both were defined as a percentage of the baseline average electricity tariff. Three years later, two options were established for the sale of wind-generated electricity: (a) to transfer the electricity in exchange for a regulated tariff, which is expressed in euro cents per $\mathrm{kWh}$, for all programming periods; (b) to sell the electricity in the electric energy production market. In the last case, the selling price of the electricity would be the one fixed at the regulated market or freely negotiated, which is later complemented by a premium in euro cents per $\mathrm{kWh}$.

52. Flores, J.; Esteve, J. Una visión general de la fiscalidad de la actividad eléctrica en España. In Los Tributos del Sector Eléctrico; Becker, F., Cazorla, L.M., Martínez-Simancas, J., Eds.; Aranzadi Thomson Reuters: Cizur Menor, Spain, 2013; pp. 145-170.

53. Pérez de Ayala, M.A. La doctrina del Tribunal Supremo sobre la base del ICIO en la construcción de parques eólicos. Estrateg. Financ. 2010, 276, 70-74.

54. Blanco, M.I. The economics of wind energy. Renew. Sustain. Energy Rev. 2009, 13, 1372-1382. [CrossRef]

55. Santos-Alamillos, F.J.; Thomaidis, N.S.; Usaola-García, J.; Ruiz-Arias, J.A.; Pozo-Vazquez, D. Exploring the mean-variance portfolio optimization approach for planning wind repowering actions in Spain. Renew. Energy 2017, 106, 335-342. [CrossRef]

56. Copena, D.; Simón, X. Enerxía eólica e desenvolvemento local en Galicia: Os parques eólicos singulares municipais. Revista Galega de Economía 2018, 27, 31-48.

57. Ellis, G.; Cowell, R.; Warren, C.; Strachan, P.; Szarka, J.; Hadwin, R.; Miner, P.; Wolsink, M.; Nadaï, A. Wind Power: Is There A “Planning Problem"? Expanding Wind Power: A Problem of Planning, or of Perception? Plan. Theory Pract. 2009, 10, 521-547. [CrossRef]

58. Ministerio de Medio Ambiente y Medio Rural y Marino. Tercer Inventario Forestal Nacional. Madrid. 2008. Available online: https://www.miteco.gob.es/es/biodiversidad/servicios/banco-datos-naturaleza/ informacion-disponible/ifn3.aspx (accessed on 25 June 2018).

59. Rodríguez-Pose, A.; Palavicini-Corona, E.I. Does local economic development really work? Assessing LED across Mexican municipalities. Geoforum 2013, 44, 303-315. [CrossRef]

60. Fast, S.; Mabee, W. Place-making and trust-building: The influence of policy on host community responses to wind farms. Energy Policy 2015, 81, 27-37. [CrossRef]

61. Del Río, P.; Burguillo, M. Assessing the impact of renewable energy deployment on local sustainability: Towards a theoretical framework. Renew. Sustain. Energy Rev. 2008, 12, 1325-1344. [CrossRef]

62. Wang, S.; Wang, S. Impacts of wind energy on environment: A review. Renew. Sustain. Energy Rev. 2015, 49, 437-443. [CrossRef]

63. Wolsink, M. Planning of renewables schemes: Deliberative and fair decision-making on landscape issues instead of reproachful accusations of non-cooperation. Energy Policy 2007, 35, 2692-2704. [CrossRef]

64. Villena-Ruiz, R.; Ramirez, F.J.; Honrubia-Escribano, A.; Gómez-Lázaro, E. A techno-economic analysis of a real wind farm repowering experience: The Malpica case. Energy Convers. Manag. 2018, 172, 182-199. [CrossRef]

65. Elola, A.; Parrilli, M.D.; Rabellotti, R. The Resilience of Clusters in the Context of Increasing Globalization. Eur. Plan. Stud. 2013, 21, 989-1006. [CrossRef] 
66. Varela-Vázquez, P.; Sánchez-Carreira, M.C. Upgrading Peripheral wind sectors. Technol. Anal. Strateg. Manag. 2016, 28, 1152-1166. [CrossRef]

67. Sovacool, B.K.; Dworkin, M.H. Energy justice: Conceptual insights and practical applications. Appl. Energy 2015, 142, 435-444. [CrossRef]

(C) 2019 by the authors. Licensee MDPI, Basel, Switzerland. This article is an open access article distributed under the terms and conditions of the Creative Commons Attribution (CC BY) license (http://creativecommons.org/licenses/by/4.0/). 